\title{
ARTYKULY
}

Jerzy Mirosław Kupiec

(Poznań University of Life Sciences

Department of Ecology and Environmental Protection)

\section{ANALYZE OF FARM NITROGEN BUDGET IN THE GEOGRAPHICAL AND HISTORICAL LAND OF WIELKOPOLSKA IN 1843-2012}

\section{Introduction}

D esearch on the history of agriculture, having a long and good tradition in Polish historical literature, didn't include the issues related to the scale 1 of production in farms and the degree of risk to the environment over the centuries. Although often people were interested to former agriculture, it is quite exceptional that it can be said about the environmental aspects of these considerations. Advancements in research on the agrarian history of Poland performed in several stages. In the first stage, extending to the beginning of the twentieth century, there appear the paperwork derived mainly from environment of the gentry. However, these were quite general reflections or sided non-scientific considerations. Much work is also devoted to socio-economic reflection included an amateur. Primarily negated manorial serf system and described its negative impact on the state of agriculture in Poland. A characteristic feature of the second period was the development of the agrarian research within the growing economic history or under the influence of progressive research associations. In the interwar period began to extend to the knowledge of the old farm, even from the medieval period. The third period started after World War II brought considerable deepening of the methods and scope of studies and turned its attention to the issues of development of production techniques ${ }^{1}$. Currently reflections on agriculture have multidimensional nature that combines social, economic and environmental aspects. However, they include current issues and rarely capture the comparison to the old farm.

The aim of the study was to assess the intensity of nitrogen management in agriculture in terms of diffuse pollution monitoring based on the field surface balance in the changing boundaries of the Wielkopolska region, with its capital in Poznan.

${ }^{1}$ I. Kostrowicka, Z. Landau, J. Tomaszewski, Historia gospodarcza Polski XIX i XX wieku, Warszawa 1984, s. 577. 


\section{Material and methods}

Agricultural statistics. Information about the structure of animal species and their abundance, structure of land use and crops, crop yield and fertilizer use are obtained with the practitioners development, agricultural activists, scribes and statistical studies ${ }^{2}$. Analyzes were made for years and collected the most complete and accurate data.

Nitrogen balance sheet. The correctness of the nitrogen management is calculated based on the field surface balance ${ }^{3}$. Some of the elements of balance structure were significant only at certain times. Later, due to changes in agricultural techniques, but also introduced legislative acts, their share decreased or completely lost its importance. Nitrogen balance formula is as follows:

$$
\mathrm{N}_{\text {budget }}=\Sigma \mathrm{N}_{\mathrm{F}}+\Sigma \mathrm{N}_{\mathrm{M}}+\Sigma \mathrm{N}_{\mathrm{S}}+\Sigma \mathrm{N}_{\mathrm{W}}+\Sigma \mathrm{N}_{\mathrm{L}}-\Sigma \mathrm{N}_{\mathrm{C}}-\Sigma \mathrm{N}_{\mathrm{G}}
$$

...where:

$\mathrm{F}$-fertilizers, $\mathrm{M}$ - solid manure, $\mathrm{S}$-slurry, $\mathrm{W}$-faecal/domestic waste water, $\mathrm{L}$-forest litter, $\mathrm{C}$-crops, $\mathrm{G}$ - yield of grassland.

${ }^{2}$ „Ziemianin. Pismo poświęcone rolnictwu i przemysłowi”, t. 1, Poznań 1950, s. 376; Rocznik Statystyczny Królestwa Polskiego, red. W. Grabski, Warszawa 1914, s. 187; Rocznik Statystyczny Królestwa Polskiego, red. W. Grabski, Warszawa 1915, s. 173; Rocznik Statystyczny Królestwa Polskiego z uwzględnieniem innych ziem polskich, red. E. Strasburger, Warszawa 1916, s. 178; E. Romer, I. Weinfeld, Rocznik Polski. Tablice Statystyczne, Kraków 1917, s. 104; Rocznik Statystyki Rzeczypospolitej Polskiej 1920/22, Główny Urząd Statystyczny, Warszawa 1923, s. 403; Tablice Statystyczne 1923, Warszawa-Bydgoszcz 1923, s. 111; Tablice Statystyczne za lata 1925 i 1926, Warszawa1927, s. 103; Mały Rocznik Statystyczny 1930, Główny Urząd Statystyczny Rzeczypospolitej Polskiej, Warszawa 1931, s. 49; Mały Rocznik Statystyczny 1934, Główny Urząd Statystyczny Rzeczypospolitej Polskiej, Warszawa 1935, s. 42; Mały Rocznik Statystyczny 1939, Główny Urząd Statystyczny Rzeczypospolitej Polskiej, Warszawa 1939, s. 424; Rocznik Statystyczny 1947, Główny Urząd Statystyczny Rzeczypospolitej Polskiej, Bydgoszcz 1948, s. 113; Rocznik Statystyczny 1948, Główny Urząd Statystyczny, Bydgoszcz 1949, s. 291; Rocznik Statystyczny 1949, Główny Urząd Statystyczny Rzeczypospolitej Polskiej, Bydgoszcz 1950, s. 339; Rocznik Statystyczny 1955, Główny Urząd Statystyczny Polskiej Rzeczypospolitej Ludowej, Warszawa 1956, s. 287; Tablice Statystyczne 1953-1954, Główny Urząd Statystyczny Polskiej Rzeczypospolitej Ludowej, Warszawa 1956, s. 93; Rocznik Statystyczny Województwa Poznańskiego, Urząd Statystyczny dla m. Poznania i Województwa Poznańskiego, Poznań 1964. XVIII, s. 337; Rocznik Statystyczny Województwa Poznańskiego, Urząd Statystyczny, Poznań 1973, s. 467; Rocznik Statystyczny Województwa Poznańskiego, Woj. Urząd Statystyczny, Poznań 1983, s. 333; Rocznik Statystyczny Województwa Poznańskiego, Wojewódzki Urząd Statystyczny, Poznań 1993, s. 295; Historia Polski w liczbach. Ludność, terytorium, Główny Urząd Statystyczny, Warszawa 1994, s. 205; Rocznik Statystyczny Województwa Wielkopolskiego, Urząd Statystyczny w Poznaniu, Poznań 2003, s. 421; Rocznik Statystyczny Województwa Wielkopolskiego, Urząd Statystyczny w Poznaniu, Poznań 2013, s. 433; C. Kuklo, J. Łukasiewicz, C. Leszczyńska, Historia Polski w liczbach. Polska w Europie, Warszawa 2014, s. 605.

${ }^{3} \mathrm{~J}$. Kupiec, J. Zbierska, Comparison of Results Obtained on the Basis of Selected Types of Nitrogen Balance in the Scale of a Field and a Farm, "Polish Journal of Environmental Studies" 2012, Vol. 21, No. 5. 
In the nitrogen balance sheet formula it was taken into account historical conditions and cultivated agricultural practices in a given period. Nutrient content were based on the results of chemical analyzes and researchers experiments of the period.

Mineral fertilizers. Due to the low interest of fertilizers in the nineteenth century and their marginal rate, this element of the balance sheet was omitted for the years 1943 and 1873. In other periods, the amount of nitrogen from fertilizers calculated on the basis of their consumption in the region. Because of the lack of data for the years 1912-1946 assumed average consumption of fertilizers for the Polish territory from that period, increased by average higher consumption in the region ( $21 \%$ more).

Manures. In the nineteenth century and the first half of the twentieth century, the handling of liquid manures was irrational and they were used in marginal extent. Therefore, for 1938, the input was calculated only for nitrogen from produced solid manure. Quantity of manure produced by livestock was calculated according to the Górski (by Niklewski ${ }^{4}$ ). The amount of nitrogen in the manure produced in this period was calculated by Mayer (by Niklewski ${ }^{5}$ ).

The amount of resulting manure in period of 1843-1955 was calculated based on Haselhoff (by Niklewski ${ }^{6}$ ) and Górski ${ }^{7}$. The amount of manure produced in the period 1961-2012 was calculated according to the guidelines the Council of Ministers of 18 May $2005^{8}$. Nitrogen content in manure produced in this period was calculated by Mazur and Górski (by Wrześniowski et al. ${ }^{9}$ ).

Straw and forest litter. In the twentieth century as bedding for animals, in the case where the straw was missing, often used the forest litter. Due to the situation of agriculture in this period mainly used materials which there was no need to pay for. Peat was too expensive so it was used as bedding marginally. The first regulations restricting this type of procedure that adversely affect the functioning of forest ecosystems, introduced at the beginning of the twentieth century. In this paperwork the amount of used forest litter counted based on the difference between the amount of straw harvested from the fields and the needs of the animals in this area ${ }^{10}$.

${ }^{4}$ B. Niklewski, Nawożenie roślin na ziemiach polskich, cz. 1-2, Poznań 1949, s. 473.

${ }^{5}$ Tamże.

${ }^{6}$ Tamże.

${ }^{7}$ M. Górski. Nawozy organiczne, Warszawa 1947, s. 190.

${ }^{8}$ Rozporządzenie Rady Ministrów z dnia 18 maja 2005 r. zmieniające rozporządzenie $w$ sprawie szczegółowych warunków i trybu udzielania pomocy finansowej na dostosowanie gospodarstw rolnych do standardów Unii Europejskiej objętej planem rozwoju obszarów wiejskich. Dz. U. 2005 nr 93, poz. 778, 779 i 780.

${ }^{9}$ Z. Wrześniowski, W. Sosnowska, R. Stempel, Tabele pomocnicze do planowania rolniczej dziatalności gospodarczej, Olsztyn 1997, s. 112.

${ }^{10}$ A. Stutzer, Nauka o nawozach. Krótkie wskazówki o własnościach i użytkowaniu nawozów użyanych w rolnictwie, Warszawa 1902, s. 139. 
The amount of straw produced in the fields was calculated based on the proportion of main crop to a by-product. The proportions were calculated on the basis of the average yield of grain and straw given by Stutzer ${ }^{11}$. It amounted to rye $1: 4$, wheat $1: 2$, barley $1: 1.3$, oats $1: 1.8$. Straw harvested from the fields is calculated on the basis of the information given by Kostrowicka et al. ${ }^{12}$ Farmers living in the nineteenth century the region of the Grand Duchy of Poznan cut the ears by hand, with sickles. The rule was to cut straw the highest as possible, so the vast majority of the straw remained on the field. In the first half of the twentieth century agriculture in the region passed through the significant modernization. The introduction of new machinery and equipment, including harvesting of cereals, also resulted in a greater yield of straw, which was useful in the intensification of animal production. Therefore, the paperwork assumed that farmers harvested the approx. 1/4 part of straw in 1843 and 1873 and 1/2 in 1912. The demand for bedding for livestock were calculated based on the individual needs of each species ${ }^{13}$. The contents of the nutrient in the forest litter was calculated by Niklewski ${ }^{14}$.

Faecal. In the nineteenth century there was not much attention paid to the storage of domestic sewage and mostly collected them in bare earthen pits, thereby liquid manures penetrated into the soil. However, they were important element of fertilization in some farms. For the period 1843-1912 there was calculated only the amount of hard excrements according to the information given in Ziemianin ${ }^{15}$. The sum of the feces was calculated for a rural population living in this region in particular periods. The nitrogen content in solid faecal were calculated by Stutzer ${ }^{16}$.

The amount of human feces used as fertilizer in the years 1922-1946 and the content of nitrogen were calculated by Stutzer ${ }^{17}$. Other authors also reported that human faeces are excellent nitrogen fertilizer ${ }^{18}$. However, in subsequent periods feces ceased to be used as fertilizer, and therefore they are not included in the balance sheet components.

\footnotetext{
${ }^{11}$ Tamże.

${ }^{12}$ I. Kostrowicka, Z. Landau, J. Tomaszewski, Historia gospodarcza ..., s. 577.

${ }^{13}$ A. Stutzer, Nauka o nawozach ..., s. 139.

${ }^{14}$ B. Niklewski, Nawożenie roślin..., s. 473.

${ }^{15}$ „Ziemianin. Pismo poświęcone rolnictwu i przemysłowi”, t. 1, Poznań 1850, s. 376.

${ }^{16}$ A. Stutzer, Nauka o nawozach..., s. 139.

${ }^{17}$ Tamże.

${ }^{18}$ F.R. Rolnik Nadwiślański, Kanalizacya miasta Warszawy jako narzędzie judaizmu i szarlataneryi w celu zniszczenia rolnictwa polskiego oraz wytępienia ludności słowiańskiej nad Wisła, Kraków 1900, s. 37.
} 


\section{Results and discussion}

\section{The characteristics of Wielkopolska} region. Area of research is the region with its capital in Poznan located in the geographical and historical land of Wielkopolska, within the changing administrative borders (Figures 1-4). Wielkopolska is a region that has signed up strongly in the history of Poland and it is strongly associated with the onset of Polish statehood ${ }^{19}$. The nineteenth century is the special century in the history of Poland because it has lost its identity as a result of the three partitions made by Austria, Prussia and Russia in 1769, 1793 and 1795. During the second partition Prussia took over, inter alia, Province Gniezno, Poznań,

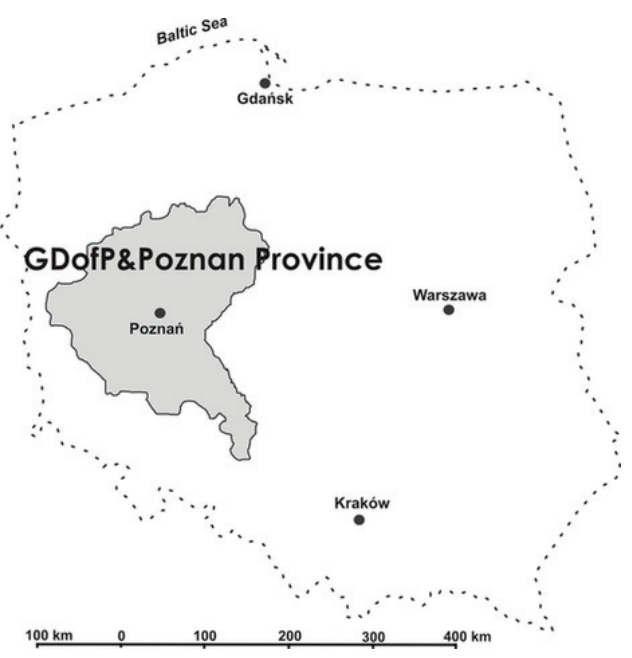

Fig. 1. Border of Grand Duchy of Poznań (1815-1848) and Poznań Province (1848-1919) in the background of the current Polish border Kalisz and land of Wielun associated with the Wielkopolska region ${ }^{20}$. The result of partition was the acquisition by the Prussia $20 \%$ of Poland territory. Austria has acquired $18 \%$ of the area. Russia took over the largest part, because $62 \%$ of the old Republic. Prussian sector, including taken Wielkopolska region, inhabited mostly by the Polish population, took the land incomparably better economically developed. All countries partitioning remained feudal system and the supremacy of the nobility over the village. In Prussia and Austria, however, partly attempted to reform the feudal relations.

In the analyzed period there can be distinguished several periods affecting the Wielkopolska region and developing agriculture there ${ }^{21}$ (Figures 5-6). Wielkopolska region throughout the period considered was at the forefront in terms of technology and agricultural productivity.

${ }^{19}$ J. Topolski, Wielkopolska jako region historyczny, [w:] Dzieje Wielkopolski. Do roku 1793, t. 1, red. J. Topolski, Poznań 1969, s. 23-30; J. Włodarczyk, Krainy historyczne Polski, Warszawa 2012, s. 144 ..

${ }^{20}$ Zarys historii gospodarstwa wiejskiego w Polsce, t. 2, red. B. Baranowski, J. Topolski, Warszawa 1964, s. 600.

${ }^{21}$ Tamże; I. Kostrowicka, Z. Landau, J. Tomaszewski, Historia gospodarcza ..., s. 577; P. Kraciński, Rozdysponowanie Własności Rolnej Skarbu Państwa w latach 1992-2009, „Zeszyty Naukowe SGGW" 2011, t. 87, s. 41-53. 


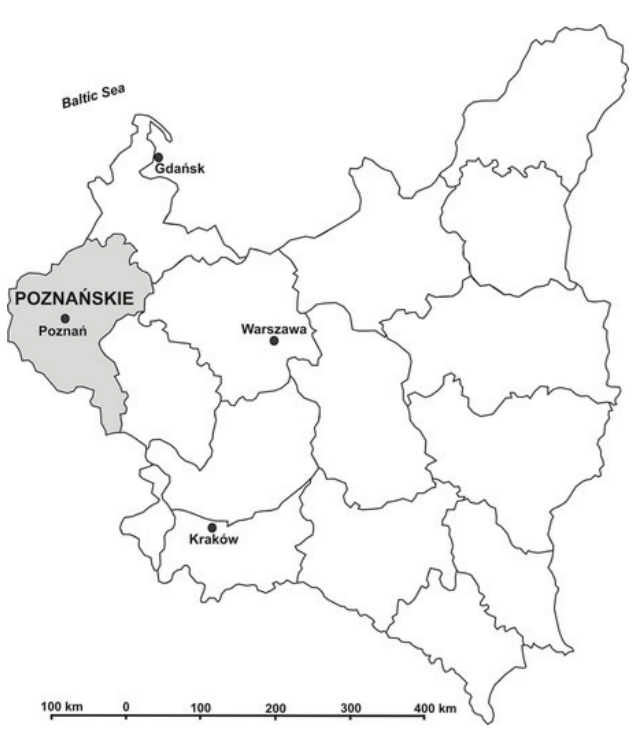

Fig. 2. Border of Poznańskie voivodeship in 1919-1939

The area of the region examined ranged from 815097 in 1992 to 3950300 ha in 1946 (Table 1). The land structure clearly marked with a dominance of agricultural land, including arable land. In the period of 1843-2014 the surface was reduced by approx. $16 \%$. Major changes took place mainly in the area of permanent grassland which decreased from 34.2 in 1843 to $8.4 \%$ in 2012. In the years 1873-1961 the share of meadows and grassland remained at a similar level (approx. 10.5\%). The smallest share of permanent grassland was observed in 1992, which was associated with political changes in Poland and the liquidation of State Agricultural Farms and Agricultural Production Cooperatives, with a considerable amount of cattle. The share of forest area in the region of Wielkopolska ranged from 17.4 to $25.7 \%$. Shortly after World War II through the lands attached Lubuskie Province, Wielkopolska Province has gained in forestation. The forest area in 1946 was $24.1 \%$ (Table 1 ).

Analyzing the share of individual plant groups in the structure of crop it can be seen that the share of cereals in crop structure underwent a fairly large fluctuations of up to $30 \%$ (Table 2). It is worth to note that even in the nineteenth century on large areas legumes were grown, which formed the basis of food, but also animal feed. In the twentieth century in the areas under these crops in the region of Wielkopolska strongly decreased and this situation remain to this day. Root crops, including potatoes, almost did not matter in the nineteenth century, because their share in the crop structure is small. In the second half of the nineteenth century, there was an increase in acreage of potatoes and sugar beets crops. Root crops occupied large cultivated areas mainly in the interwar period (Table 2). Currently root crops constitute a small share in the sowing structure. Growing state after World War II quickly returned to normal. 

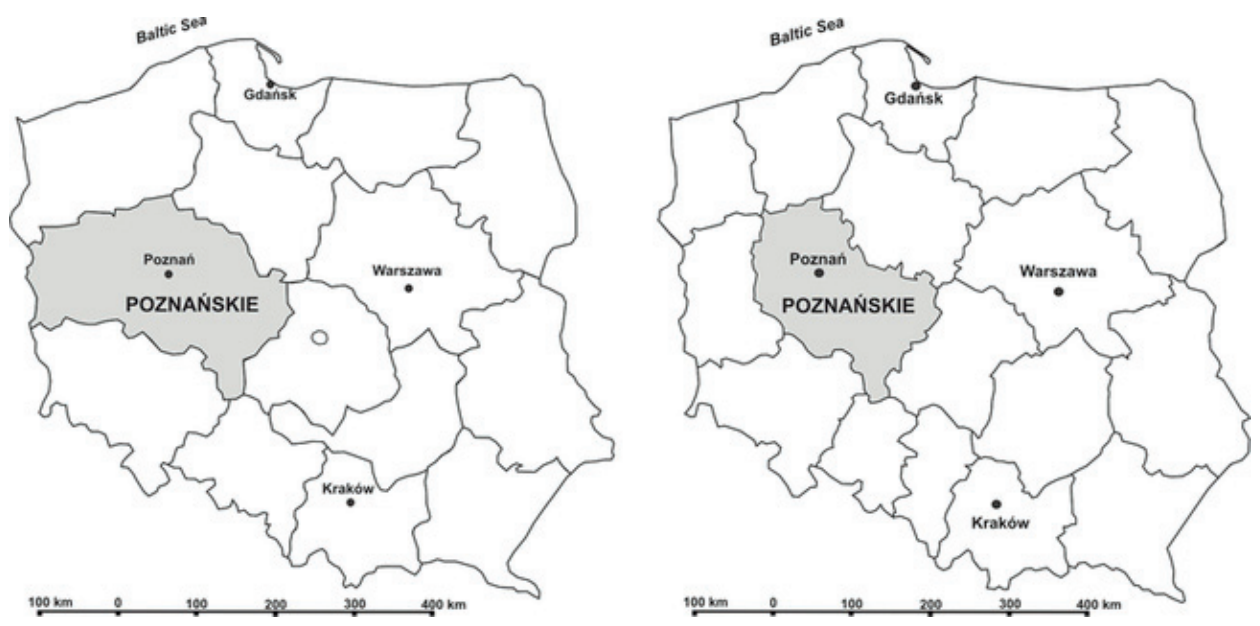

Fig. 3. Border of Poznańskie voivodeship in 1946-1950 and 1950-1975
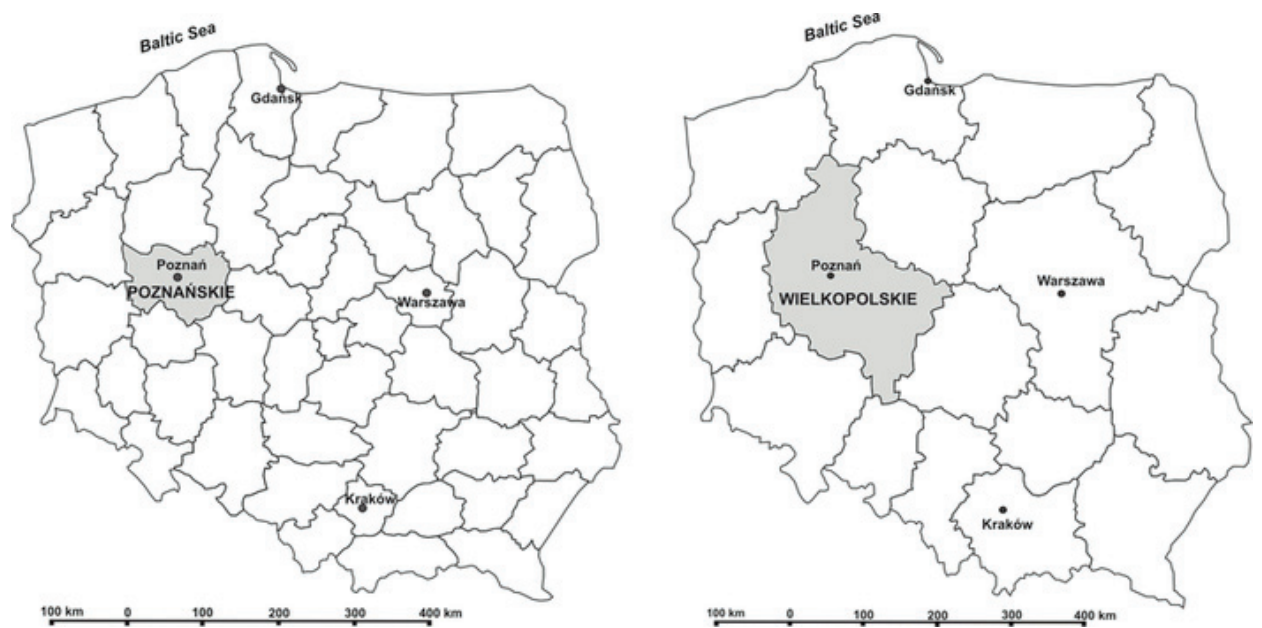

Fig. 4. Border of Poznańskie voivodeship in 1975-1998 and Wielkopolskie voivodeship in 1998-2014 
Fig. 5

Historic events

the creation of the Duchy of Warsaw. Duchy of Poznan has become the one
of the six departments

Fig. 6

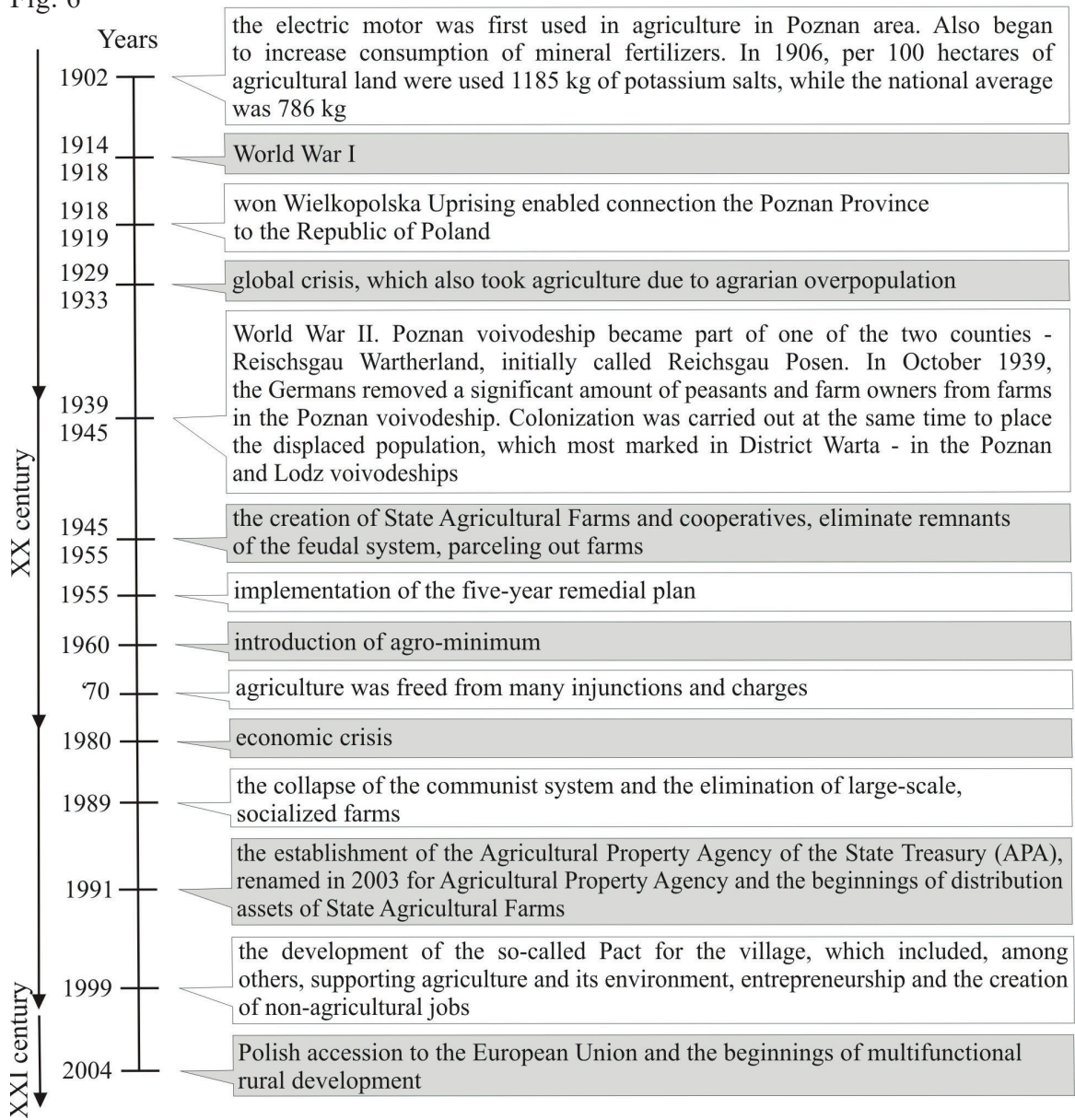

Fig. 5-6. Historical and morphogenetic factors affecting the development of agriculture in the analyzed region in XIX, XX and XXI centuries 
Table 1

Land use structure in particular periods

\begin{tabular}{|c|c|c|c|c|c|c|c|}
\hline \multirow{2}{*}{ Year } & $\begin{array}{c}\text { Surface } \\
\text { region }\end{array}$ & $\begin{array}{c}\text { Agricultural } \\
\text { land }\end{array}$ & $\begin{array}{c}\text { Arable } \\
\text { land with } \\
\text { orchards } \\
\text { and gardens }\end{array}$ & Meadows & Pastures & $\begin{array}{c}\text { Woods, } \\
\text { forests and } \\
\text { woodlots }\end{array}$ & $\begin{array}{c}\text { Other } \\
\text { and and } \\
\text { wasteland }\end{array}$ \\
\cline { 2 - 9 } & [ha] & \multicolumn{5}{|c|}{ [\%] } \\
\hline 1843 & 2987010 & 74.8 & 40.6 & 14.1 & 20.1 & 20.5 & 4.7 \\
\hline 1873 & 2895239 & 74.9 & 61.6 & 8.1 & 5.2 & 20.2 & 4.9 \\
\hline 1912 & 2899000 & 75.0 & 64.6 & 7.8 & 2.6 & 18.1 & 6.9 \\
\hline 1922 & 2657929 & 76.0 & 65.6 & 7.8 & 2.6 & 18.1 & 5.9 \\
\hline 1931 & 2835000 & 75.1 & 64.6 & 7.1 & 3.4 & 17.4 & 7.5 \\
\hline 1938 & 2835000 & 75.1 & 64.6 & 7.1 & 3.4 & 17.4 & 7.5 \\
\hline 1946 & 3950300 & 67.8 & 57.4 & 7.5 & 2.8 & 24.1 & 8.1 \\
\hline 1955 & 2744300 & 69.9 & 59.0 & 6.9 & 4.0 & 19.8 & 10.3 \\
\hline 1961 & 2672269 & 70.5 & 59.7 & 7.0 & 3.9 & 21.7 & 7.8 \\
\hline 1972 & 2684885 & 66.7 & 55.7 & 7.8 & 3.2 & 23.6 & 9.7 \\
\hline 1982 & 822757 & 66.4 & 58.6 & 5.7 & 2.2 & 20.9 & 12.7 \\
\hline 1992 & 815097 & 66.2 & 58.6 & 5.4 & 2.2 & 21.1 & 12.7 \\
\hline 2002 & 2982559 & 59.6 & 51.2 & 6.8 & 1.5 & 25.7 & 14.7 \\
\hline 2012 & 2982559 & 58.8 & 50.4 & 7.6 & 0.8 & 25.7 & 15.5 \\
\hline
\end{tabular}

Source: compilation and own calculations based on: see ibid. 2 .

Table 2

Structure of crops in investigated periods

\begin{tabular}{|c|c|c|c|c|c|c|}
\hline \multirow[t]{2}{*}{ Year } & Cereals & Fabaceae & $\begin{array}{c}\text { Industrial } \\
\text { and special } \\
\text { plants } \\
\end{array}$ & Forage crops & Root plants & Others \\
\hline & \multicolumn{6}{|c|}{$[\%]$} \\
\hline 1843 & 80.3 & 17.0 & 0.8 & 0.0 & 0.6 & 1.3 \\
\hline 1873 & 71.3 & 17.6 & 0.7 & 0.6 & 9.1 & 0.7 \\
\hline 1912 & 63.4 & 4.6 & 0.0 & 7.3 & 20.0 & 4.6 \\
\hline 1922 & 69.7 & 0.0 & 0.0 & 0.0 & 30.3 & 0.0 \\
\hline
\end{tabular}


Table 2 (continued)

\begin{tabular}{|c|c|c|c|c|c|c|}
\hline \multirow[t]{2}{*}{ Year } & Cereals & Fabaceae & $\begin{array}{c}\text { Industrial } \\
\text { and special } \\
\text { plants }\end{array}$ & Forage crops & Root plants & Others \\
\hline & \multicolumn{6}{|c|}{$[\%]$} \\
\hline 1931 & 71.8 & 1.5 & 0.2 & 0.0 & 26.4 & 0.1 \\
\hline 1938 & 73.8 & 1.1 & 0.9 & 0.0 & 24.1 & 0.0 \\
\hline 1946 & 66.0 & 2.4 & 2.6 & n.d. & 17.2 & 11.8 \\
\hline 1955 & 50.9 & n.d. & n.d. & n.d. & 22.6 & 26.5 \\
\hline 1961 & 53.5 & 0.5 & 2.4 & 15.8 & 25.6 & 2.2 \\
\hline 1972 & 60.9 & 5.7 & 3.3 & 0.0 & 28.0 & 2.2 \\
\hline 1982 & 50.3 & 9.1 & 3.5 & 10.6 & 22.1 & 4.4 \\
\hline 1992 & 56.6 & 7.8 & 7.2 & 6.8 & 16.1 & 5.5 \\
\hline 2002 & 79.0 & 2.1 & 5.7 & 0.0 & 10.5 & 2.8 \\
\hline 2012 & 70.0 & 3.8 & 7.4 & 7.9 & 7.3 & 3.5 \\
\hline
\end{tabular}

Source: compilation and own calculations based on: see ibid. 2 .

The number of animal species kept in holdings in Wielkopolska region has changed over time. The population of horses remained relatively equal level in the period 1843-1961 (Table 3). In the later period, the number of horses in the region has decreased dramatically. This was mainly associated with increased mechanization of agriculture. The horses lost their significance as draft animals. In the period under review decreased significantly sheep and goats from approx. $28 \%$ to the marginal amount. Cattle remained relatively constant over the considered period of time. In 1992, lowest share of cattle recorded in the structure of species inventory. This was mainly due to unfavorable changes in the rural economy of the country. Swine, which in the nineteenth century accounted for only $4 \%$ of the inventory, in the twentieth century has gained in importance. In the analyzed period the share of swine in inventory increased to $51 \%$ (Table 3). During this period, significantly increased the population of poultry. For a long time poultry maintained only for their own use because poultry did not provide an adequate income. Only after 2000, there is clear interest in this department of animal production. During World War II into the territories of province Germany imported more valuable breeding material and after war village received state support in the form of livestock, fertilizers, reconstruction of buildings and seeds. 
Structure of animal species in analyzed periods

\begin{tabular}{|c|c|c|c|c|c|c|}
\hline \multirow{2}{*}{ Year } & Horses & Cattle & Swine & Sheep/goats & $\begin{array}{c}\text { Poultry } \\
\text { /rabbits }\end{array}$ & $\begin{array}{c}\text { Summary } \\
\text { LSU = 100\% }\end{array}$ \\
\cline { 2 - 7 } & \multicolumn{5}{|c|}{$[\%]$} \\
\hline 1843 & 23 & 54 & 4 & 17.3 & 2.4 & 761720 \\
\hline 1873 & 21 & 45 & 4 & 27.5 & 2.4 & 1027499 \\
\hline 1912 & 25 & 59 & 10 & 2.8 & 2.4 & 1291512 \\
\hline 1922 & 23 & 62 & 9 & 3.5 & 2.4 & 1135712 \\
\hline 1931 & 27 & 58 & 11 & 2.3 & 2.4 & 1222246 \\
\hline 1938 & 26 & 59 & 10 & 2.7 & 2.4 & 1594893 \\
\hline 1946 & 29 & 55 & 10 & 3.0 & 2.0 & 998343 \\
\hline 1955 & 24 & 55 & 16 & 2.2 & 3.1 & 1140980 \\
\hline 1961 & 22 & 55 & 18 & 3.0 & 1.6 & 1241843 \\
\hline 1972 & 16 & 54 & 26 & 2.5 & 0.9 & 1403648 \\
\hline 1982 & 6 & 52 & 37 & 4.4 & 1.3 & 485248 \\
\hline 1992 & 5 & 41 & 51 & 2.4 & 1.0 & 438105 \\
\hline 2002 & 2 & 55 & 29 & 0.6 & 14.0 & 1320250 \\
\hline 2012 & 2 & 50 & 31 & 0.4 & 16.4 & 1200834 \\
\hline
\end{tabular}

Source: compilation and own calculations based on: see ibid. 2 .

Nitrogen balance. Nitrogen balance sheet structure changed over time (Table 4). Yet in the nineteenth century mineral fertilizers were used on a small scale. Mostly it was calcium fertilizers such as gypsum or lime. In addition, applied mineral fertilizers to change the soil structure, such as sand, ordinary clay, blows clay, marl. Other mineral fertilizers were expensive, but also not much attention was paid to the mineral nutrients. Much attention has focused on organic matter. The main source was the straw left on the field as well as manure. Also there were used other mineral fertilizers, mineral-organic or organic ones such as wood ash, roasted or minced bones, blood, powdered feces, compost, peat, mud street containing manure or feces, forest litter, peat soaked with liquid manure, moss with feces or mud river or fermented dung obtained from plants or animal residues. About some fertilizers it was only written in publications. In practice, they were used on a very 
Structure of nitrogen balance in farms of Wielkopolska region in analyzed periods

\begin{tabular}{|c|c|c|c|c|c|c|c|c|c|c|}
\hline \multirow[b]{3}{*}{$\stackrel{\bar{\nu}}{\grave{\nu}}$} & \multicolumn{6}{|c|}{ Input $\mathbf{N}$ kg $\cdot \mathrm{ha}^{-1} \mathbf{A L}$} & \multicolumn{3}{|c|}{ Output $\mathbf{N ~ k g} \cdot \mathrm{ha}^{-1}$ AL } & \multirow{3}{*}{$\frac{\stackrel{\Xi}{\Xi}}{\frac{\Xi}{\tilde{J}}}$} \\
\hline & \multirow{2}{*}{  } & \multicolumn{2}{|c|}{ Manures } & \multirow[b]{2}{*}{ 焉 } & \multirow[b]{2}{*}{ 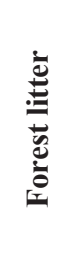 } & \multirow{2}{*}{ 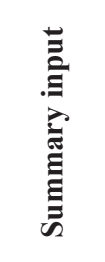 } & \multirow[b]{2}{*}{ 仓ै } & \multirow[b]{2}{*}{ 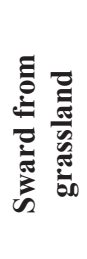 } & \multirow{2}{*}{  } & \\
\hline & & 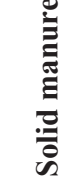 & $\stackrel{\vec{E}}{\vec{E}}$ & & & & & & & \\
\hline 1843 & - & 8.06 & - & 1.48 & 0.66 & 10.20 & 4.22 & 26.42 & 30.64 & -20.44 \\
\hline 1873 & - & 9.91 & - & 1.86 & 0.16 & 11.93 & 34.23 & 11.05 & 45.28 & -33.35 \\
\hline 1912 & 0.09 & 15.90 & - & 2.25 & 1.71 & 19.94 & 29.76 & 9.08 & 38.84 & -18.90 \\
\hline 1922 & 0.56 & 14.68 & - & 2.62 & - & 17.86 & 17.76 & 8.85 & 26.61 & -8.75 \\
\hline 1931 & 1.88 & 15.15 & - & 3.17 & - & 20.20 & 23.53 & 8.82 & 32.36 & -12.15 \\
\hline 1938 & 2.15 & 19.51 & - & 3.18 & - & 24.83 & 20.57 & 8.82 & 29.39 & -4.56 \\
\hline 1946 & 4.94 & 9.80 & 4.33 & 3.13 & - & 22.21 & 37.36 & 22.54 & 59.90 & -37.69 \\
\hline 1955 & 12.90 & 15.43 & 6.95 & - & - & 35.28 & 55.56 & 3.32 & 58.88 & -23.60 \\
\hline 1961 & 22.00 & 40.21 & 18.04 & - & - & 80.25 & 37.75 & 2.40 & 40.15 & 40.10 \\
\hline 1972 & 58.70 & 50.42 & 25.80 & - & - & 134.92 & 41.64 & 3.09 & 44.73 & 90.19 \\
\hline 1982 & 83.10 & 47.95 & 29.54 & - & - & 160.59 & 53.95 & 2.92 & 56.87 & 103.72 \\
\hline 1992 & 50.30 & 55.32 & 31.70 & - & - & 137.33 & 50.64 & 2.02 & 52.66 & 84.67 \\
\hline 2002 & 62.90 & 37.69 & 26.53 & - & - & 127.11 & 54.26 & 3.48 & 57.74 & 69.38 \\
\hline 2012 & 92.60 & 31.73 & 20.73 & - & - & 145.06 & 69.58 & 3.96 & 73.54 & 71.52 \\
\hline
\end{tabular}

Source: own calculations. 
small scale ${ }^{22}$. Even in the first two decades of the last century divided fertilizers for full fertilizers and auxiliary fertilizers. Full fertilizer included manure and compost, it provided a full range of essential nutrients for plants ${ }^{23}$. These fertilizers were considered to be the most important in the farm. To auxiliary fertilizers included mineral fertilizers and green manures, which have been used rarely. Compost, according Stutzer ${ }^{24}$ was either unknown, or the farmers were not able to prepare it.

In the nineteenth century still the dominant system of crop were different varieties of three-field system. Inadequate fertilization and cultivation sided, almost exclusively ear plants forced to annually shut down of service approximately $1 / 3$ of arable land to make fertility to be able to regenerate. This system of cultivation was practiced in almost all contemporary Europe. The possibility of fertilizing during this period remained in direct relation to the level of livestock amount ${ }^{25}$.

Consumption of nitrogen from manure from the nineteenth century increased (Table 4). Decrease in the use of this fertilizer observed after the World War II, when agriculture was significantly weakened by the war and the number of animals decreased. The largest use of nitrogen from manure observed in 1992. The economic transformation in Poland influenced at this fact. The collapse of farms with large-scale farming cattle breeding caused that farms providing faster capital turnover, including farms with pigs, were more intensive developed. Intensive breeding of these animals causes increased amounts of manure and slurry. During this period, province of Poznan was a small area and around the capital of the region were focused large farms and large-scale intensive farms (Figure 4). The region was deprived of districts with the extensive agricultural production - czarnkowsko-trzcianecki district, złotowski district, pilski district, chodzieski district or wągrowiecki district. And so there is higher consumption of nitrogen per 1 ha. At higher loads of agricultural land could also affect the structure of the animals herd. Slurry nitrogen consumption in the period also increased (Table 4). In the nineteenth century and the first half of the twentieth century consumption of liquid manure was minimal due to their underestimation. Animals in stock places were kept mostly on the bare ground, because this liquid manure penetrated directly into the ground. In practice under 50 twentieth century does not use slurry as fertilizer ${ }^{26}$. Sometimes land in farm buildings was paved or lined with brick.

${ }^{22}$ „Ziemianin. Pismo poświęcone rolnictwu i przemysłowi”, t. 1, Poznań 1950, s. 376; E. Godlewski, Pogadanka o pokarmach roślinnych. O nawozach sztucznych, Kraków 1901, Rok VIII, Serya II, 34, s. 128.

${ }^{23}$ K. Langie, Nawozy pomocnicze, sztuczne i zielone. Praktyczny podręcznik dla rolników, leśników i szkót rolniczych, Kraków 1920, s. 35.

${ }^{24}$ A. Stutzer, Nauka o nawozach..., s. 139.

${ }^{25}$ Zarys historii gospodarstwa ..., s. 600.

${ }^{26}$ B. Niklewski. Nawożenie roślin..., s. 473. 
However, the loss of liquid manure at the floor of this type were still large Stutzer ${ }^{27}$. Farmers in the nineteenth century rarely had tanks for liquid manure. Even if they did, it were often earth structures, with limestone or clay walls. So the loss of this type of fertilizer were significant. After World War II, because of the need for fertilizing, new agrarian techniques and scientific advances, this type of fertilizer was used much more willingly than before.

In the case of nitrogen balance in the studied region from 1843 to 1955 it can be observed negative balances of up to approx. $-38 \mathrm{~kg} \mathrm{~N} \cdot \mathrm{ha}^{-1} \mathrm{AL}$ (Table 4). After this period, there has been recorded only positive balance. This was influenced mainly by carried out after World War II land reforms and the introduction of the so-called agrominimum $^{28}$. From an environmental point of view, the negative balance does not constitute a threat to the environment because farms did not generate surplus nitrogen. However, longer growing of plants in such a system could lead to a unilateral depletion of nutrients from the soil and decrease the quantity and quality of the crop. Therefore, in the nineteenth century and on the beginning of the twentieth century the main system of cultivation was the three-field allowing the soil to regenerate. After World War II in 1946, the component amount collected from the field was even higher than before the war. In 1945, the sowing area in Polish lands was $90 \%$ of the state before World War II and agriculture received a strong boost of assistance from the state. To the high collection are composed exceptionally favorable weather conditions during this period.

In 1961, it can be already seen the effects of intensification of agricultural production, which was selected after the end of World War II. Nitrogen balance was periodically grew until 1982, when it was over three times more than the requirements of the Code of Good Agricultural Practice (2004) ${ }^{29}$ and more than double the recommended by Toczyński et al. $(2013)^{30}$ (Table 4). In the twenty-first century balances fell, due to adverse socio-economic phenomenon, but also more sustainable agricultural economy after Polish accession to the European Union. Still, they were the balances exceeding the recommended standards. According to Toczyński et al. (2013) ${ }^{31}$, optimum balance for nitrogen in the Wielkopolska region was within $55.9-65.9 \mathrm{~kg} \mathrm{~N} \cdot \mathrm{ha}^{-1}$. Balance after 1961 were sometimes much higher.

${ }^{27}$ A. Stutzer, Nauka o nawozach ..., s. 139.

${ }^{28}$ Elementary requirements for agronomic and breeding procedures, determining rational farming. They were introduced by Resolution No. 347 of the Council of Ministers of 22 October 1963 on agrominimum.

${ }^{29}$ Kodeks Dobrej Praktyki Rolniczej, red. I. Duer, M. Fotyma, A. Madej, 2004, s. 93.

${ }^{30}$ T. Toczyński, W. Wrzaszcz, J.S. Zegar, Zrównoważenie polskiego rolnictwa, Powszechny Spis Rolny 2010, Warszawa 2013, s. 219.

${ }^{31}$ Tamże. 


\section{Conclusions}

Nitrogen management in farms in geographical and historical region of Wielkopolska were characterized by different intensity in the analyzed periods. Mostly, however, it was unbalanced in terms of economic and environmental. Due to different historical events that have had an impact on the development of the region, the level of intensity of agricultural production fluctuated quite strongly. Feudal relations prevailing in the nineteenth and early twentieth century were not conductive to economic changes in agriculture and did not contribute to improvement of the level of production. Extensive agriculture in this period did not generate nitrogen surplus. The interwar period due to the difficult situation of geo-political and economic crisis in the country and the crisis in years 1929-1933 also contributed to the lack of this nutrient surpluses. A socialist economy, in turn, favored nitrogen surpluses due to the availability and low cost of fertilizers, the intensification of livestock production and the lack of environmental standards. The situation changed drastically after the fall of communism and the Polish accession to the European Union.

Jerzy Mirostaw Kupiec

\section{ANALIZA BUDŻETU AZOTU W GOSPODARSTWACH HISTORYCZNO- -GEOGRAFICZNEJ KRAINY WIELKOPOLSKI W LATACH 1843-2012}

Celem pracy była ocena intensywności gospodarowania azotem w rolnictwie na podstawie bilansu na powierzchni pola w zmieniających się granicach regionu Wielkopolski ze stolicą w Poznaniu. Do badań wybrano 14 okresów na przełomie trzech wieków - XIX, XX i XXI. Powierzchnia badanego regionu wahała się od $8151 \mathrm{~km}^{2}$ w 1992 r. do $39503 \mathrm{~km}^{2}$ w 1946 r. W XIX w. obszar Wielkopolski znajdował się pod panowaniem pruskim. Region ten miał jednak dużo większą autonomię niż ziemie w pozostałych zaborach. Dzięki temu rolnictwo rozwijało się tutaj dość prężnie. Bardzo szybko wzrastała ilość gospodarstw stosujących maszyny i urządzenia rolnicze. To tutaj po raz pierwszy zastosowano motor elektryczny w rolnictwie, czy też wprowadzono aparat udojowy. Zaczęto też stosować zwiększone dawki nawozów mineralnych, które praktycznie do II wojny światowej w wielu regionach kraju były traktowane jako pomocnicze. We wszystkich analizowanych okresach kultura rolna była tutaj dużo bardziej rozwinięta niż w pozostałych regionach kraju.

Azot jest jednym z najważniejszych składników plonotwórczych. Jego nadwyżki, niewykorzystane w produkcji rolniczej, ulegają rozproszeniu w środowisku, wywołując w nim niekorzystne zmiany. Obliczony w pracy bilans azotu uzależniony był w głównej mierze od sytuacji gospodarczo-politycznej oraz administracyjnej, która wpływała na stopień intensyfikacji produkcji rolnej tego regionu. Zabory, dwie wojny światowe, zmiana stosunków społecznych na wsi oraz ustroju państwa, przemiany gospodarcze, światowy kryzys agrarny w okresie międzywojennym, nieudolne reformy na wsi w okresie powojennym, wprowadzenie agrominimum w latach 60 . XX w., czy nowe problemy gospodarki kapitalistycznej po 1989 r. wpływały na fluktuacje intensywności gospodarowania w rolnictwie. Miało to swoje odzwierciedlenie w wynikach bilansu azotu. 
Salda obliczonego bilansu wahały się w zakresie od - 33,69 do $103,72 \mathrm{~kg} \mathrm{~N} \cdot \mathrm{ha}^{-1}$ UR. Do roku 1955 saldo azotu wykazywało wartości ujemne. Z sozologicznego punktu widzenia jest to saldo poprawne, ponieważ nie powstają nadwyżki tego składnika, które mogą ulec rozproszeniu w środowisku i zagrażać jakości ekosystemów naturalnych. Uwzględniając jednak aspekt gospodarczo-ekonomiczny nie jest to sytuacja akceptowalna. Minusowe saldo oznacza, że więcej składnika jest wynoszone z pola niż na nie trafia. W dłuższej perspektywie czasu może to doprowadzić do jednostronnego wyczerpania składnika z gleby oraz obniżenia wskaźników biologicznych i produkcyjnych plonu. Po 1955 r. notowano już tylko salda dodatnie, co było spowodowane wzrostem intensywności gospodarowania, ale także zwiększonym zużyciem nawozów mineralnych. 